\title{
Mitigating the economic impact of COVID-19 pandemic on nuclear medicine: a different viewpoint
}

\author{
Y. M. AIDalilah ${ }^{1}$ A. Chiti ${ }^{2,3} \cdot$ Jamshed Bomanji $^{1}$ \\ Published online: 21 August 2020 \\ (C) Springer-Verlag GmbH Germany, part of Springer Nature 2020
}

In this day and age of COVID-19, the post-COVID era, and the new normal, most nuclear medicine departments will have lost between 15 and $30 \%$ of their full capacity $[1,2]$ in order to meet the requirements of infection control and social distancing $[3,4]$. This new normal will remain with us until we manage to control/treat/immunize against the virus [5]. The fallout from the COVID-19 pandemic is now materializing. The carnage is all around, brutal contraction of western economies, increased un-employment, collapse of air travel, and tourism are but a few examples. In health services, it is predicted that the austerity drives will start soon [6]. As service departments (nuclear medicine/imaging), we are always on the back-foot trying to justify everything we do. PostCOVID-19, our managers, for their own job security, will promise to make units efficient and profitable and they usually do so by increasing the numbers scanned or cutting costs. But a third road to sustainability is rarely mentioned: Putting Prices Up. Managers frequently fail to ask how they might do better at plucking the goose to obtain the most feathers with the least hissing. The spiel from the management consultants who advise the health services on pricing - whether specialist individuals or giant generalists like Deloitte or PWC (https://www.pwc.com/us/en/library/covid-19/pdf/pwc-ushealth-covid-19-survey-healthcare-providers 5-11.pdf) - is that it is now more vital than ever to be smart at it. In today's austere age, many units cannot depend on rising patient

This article is part of the Topical Collection on Editorial

Jamshed Bomanji

jamshed.bomanji@nhs.net

1 Institute of Nuclear Medicine, University College London Hospital, 5th Floor 235 Euston Road, London NW1 2BU, UK

2 Humanitas Clinical and Research Center - IRCCS, via Manzoni 56, 20089 Rozzano, Mi, Italy

3 Department of Biomedical Sciences, Humanitas University, Via Rita Levi Montalcini 4, 20090 Pieve Emanuele, Milan, Italy activity volumes to lift their profits. As for cutting costs, most units have already pared them to the bone to the extent that it compromises the quality and occasionally patient safety and pushed further may lead to closure of the service. Prices are all that is left. And a service can do a lot with clever pricing, to boost its share of the limited health care spending-power that is out there.

So how do we do this? Let us draw some parallels, e.g., makers of large volume high-tech products such as Apple, Samsung, and Huawei can opt to add slick new features and push up prices (https://marketrealist.com/2014/02/applespremium-pricing-strategy-product-differentiation/). Another example is the case of luxury goods, their exclusivity (Brands) is a large part of their appeal, and this in turn is a function of their price, so firms usually have scope for limiting supply and charging more: Lamborghini, a sports-car maker, and Louis Vuitton, a purveyor of classy bags, have both done this in the past. But raising prices by making products and services better or more exclusive is a tactical decision, open to only a few types of business. For us in the health care sector who provide services which extend from the mundane to the high tech, there is much that can be done tactically. It should be noted these days the drive is about infection control, quality, and safety of service. In other words, to charge more for the same thing but add the high quality and patient safety provided and track record of new research etc.

First, the nuclear medicine departments should simply take pricing more seriously: have a clear policy and make everyone stick to it. Obvious? At a recent ZOOM business seminar, the 110 or so delegates were asked if their departments/units had a written pricing policy. Just five did so. Finally, we also need a team to sell this price increase in a palatable form to our pay masters (insurers, health care systems, and self-paying patients). Establishing prices, service promotions, and discounts is often left to junior people. Even where a policy is set from the top, the junior people may ignore it (https://hbswk.hbs. edu/item/fixing-the-marketing-ceo-disconnect) because they are still being rewarded for keeping the patient booking 
numbers on par and maintaining the status quo of referral streams from other hospitals. A pricing expert says he sometimes starts his meetings by asking: "When was the last time you congratulated a manager for walking away from a hospital seeking nuclear medicine services?" Most have never done so.

Secondly, we as nuclear medicine providers need to remember, hospitals and departments do not only buy our services but they also get the high level expertise that we deliver for these services. So, nuclear medicine providers that fail to identify what benefits they are offering each type of health customer are likely to be undercharging some of them. An example is equipment-makers who sell to other businesses can be especially prone to a "cost-plus" mentality, in which they charge similar margin to everybody instead of recognizing those that are less price-sensitive and finding ways to earn more from them. Electricity companies, for example, can suffer huge costs if a transformer or its line goes down, so the transformer-makers could charge them a premium for guaranteed same-day dispatch of spares.

\section{Unbundling price}

Airlines have learned to "unbundle" their product, charging separately for baggage and meals and increasing their overall takings, it will be interesting to see what other measures are implemented in the current environment. But the nuclear medicine service providers may still charge the same to other users who never call their technical helpline as to those who ring it daily. Manufacturers of everything from cars to computers to software developers have gone further in selling benefits rather than products, by offering "power by the hour" agreements in which customer's only pay when they use their goods. A good example in the software industry is offering a basic, and usually limited, version of the software for free, and asking to pay a subscription fee to access premium features. The subscription scheme insures constant revenue to the company which increases as the user base grows (https://zoom. us/pricing). In some parts, the health service is doing the same, but in a very crude manner. The suppliers earn more overall, while the health service preserves scarce capital.

A third route to charging more is to manage user' expectations better. Once users know that a nuclear medicine department's price list is a work of fiction (as most health care prices are) and that it will resort to discounts as soon as the number of referrals dip (like we do with other hospitals), it will be a long haul to get them used to paying full agreed price, let alone accepting increases. We must look at DHL, a logistics firm, which spent years drilling into its customers that whatever the economic conditions, there will be a rate rise each year (https://www.dhl.com/us-en/home/press/press-archive/2019/ dhl-express-announces-annual-price-adjustments-in-the-us. $\mathrm{html}$ ), which is small but is not felt and there is no complaint.

\section{You've been framed}

Fourth, there are loads of simple presentational tricks that almost everyone is wise to but which still, amazingly, work. Restaurants add some overpriced wines at the top of the menu to make the ones at the bottom seem affordable (https://www. bbc.com/future/article/20171120-the-secret-tricks-hiddeninside-restaurant-menus). Makers of ice cream offer " $33 \%$ extra free" rather than " $25 \%$ off" the cost of the normal size, even though these are arithmetically the same thing. Buyers at big industrial firms are just as susceptible to such "framing" when reviewing a list of widget prices, we see this all the times.

Talk to a pricing expert and they make it sound so easy. But there are limits to how far departments like imaging can go in tailoring their prices to their user base without appearing sneaky. Although a user may not notice the odd price rise slipped in here and there, they will eventually notice if their overall bill starts to swell:

Finally, sticking to a pricing strategy takes guts. The irony is that departments like ours have such a taboo against letting go of a service user that we are the worst at taking our own advice to be fearless in asking for more, and walking away if we do not get it.

\section{Key takeaway}

Nuclear medicine departments should holistically examine their cost structure, establish a written pricing policy, develop an operational plan, and establish an operating model taking the post-COVID-19 "new normal" into consideration.

\section{Compliance with ethical standards}

Conflict of interest The authors declare that they have no conflict of interest.

Informed consent Not applicable.

Ethical approval Institutional Review Board approval was not required because the paper is an Editorial.

\section{References}

1. Naidich JJ, Boltyenkov A, Wang JJ, Chusid J, Hughes D, Sanelli PC. Impact of the coronavirus disease 2019 (COVID-19) pandemic on imaging case volumes. J Am Coll Radiol. 2020;17:865-72. https:// doi.org/10.1016/j.jacr.2020.05.004. 
2. Freudenberg LS, Paez D, Giammarile F, Cerci JJ, Modiselle M, Pascual TNB, et al. Global impact of COVID-19 on nuclear medicine departments: an international survey in April 2020. J Nucl Med. 2020. https://doi.org/10.2967/jnumed.120.249821.

3. Tulchinsky M, Osmany S. The American College of Nuclear Medicine Guidance on operating procedures for a nuclear medicine facility during COVID-19 pandemic. Clin Nucl Med. 2020. https:// doi.org/10.1097/RLU.0000000000003146.

4. Paez D, Gnanasegaran G, Fanti S, Bomanji J, Hacker M, Sathekge $\mathrm{M}$, et al. COVID-19 pandemic: guidance for nuclear medicine departments. Eur J Nucl Med Mol Imaging. 2020;47:1615-9. https:// doi.org/10.1007/s00259-020-04825-8.
5. Leung K, Wu JT, Liu D, Leung GM. First-wave COVID-19 transmissibility and severity in China outside Hubei after control measures, and second-wave scenario planning: a modelling impact assessment. Lancet. 2020;395:1382-93. https://doi.org/10.1016/ S0140-6736(20)30746-7.

6. Cavallo JJ, Forman HP. The economic impact of the COVID-19 pandemic on radiology practices. Radiology. 0:201495. https://doi. org/10.1148/radiol.2020201495.

Publisher's note Springer Nature remains neutral with regard to jurisdictional claims in published maps and institutional affiliations. 